Aspirasi: Jurnal Masalah-Masalah Sosial | Volume 11, No. 1 Juni 2020

ISSN: 2086-6305 (print) ISSN: 2614-5863 (electronic)

doi: 10.22212/aspirasi.v11i1.1590

link online: http://jurnal.dpr.go.id/index.php/aspirasi/index

\title{
Bencana Banjir: Pengawasan dan Pengendalian Pemanfaatan Ruang Berdasarkan UU Penataan Ruang dan RUU Cipta Kerja
}

\author{
Flood Disaster: Supervision and Control Utilization Spaces \\ in the Spatial Law and the Job Creation Bill
}

\author{
Sri Nurhayati Qodriyatun \\ sri.qodriyatun@dpr.go.id \\ Pusat Penelitian Badan Keahlian DPR RI \\ Jl. Gatot Subroto, Senayan, Jakarta
}

Naskah diterima: 31 Maret 2020 | Naskah direvisi: 7 Juni 2020 | Naskah diterbitkan: 30 Juni 2020

\begin{abstract}
Floods almost occurred in most parts of Indonesia, including in Bengkulu. The cause of floods in Bengkulu is more due to human behavior factors, namely massive land conversion. Even though the Spatial Planning Law already regulates how the use of space should be done and how to control it. On the other hand, the government is currently planning to change the rules regarding spatial planning to facilitate licensing in investment through the Job Creation Bill. In the bill, the authority of spatial planning is the authority of the central government. The problem is how the supervision and control of spatial use are carried out in Bengkulu and what about the supervision of spatial use control later if the spatial planning authority is centralized in the central government? By using a literature study, the study shows that the central government and the regional government of Bengkulu have not conducted supervision and control over spatial use as stipulated in the Spatial Planning Law. It was proven that it only conducted a review of Bengkulu Province Spatial Planning without conducting law enforcement for violations of spatial use. On the other hand, the spatial audit conducted by the Ministry of Agrarian Affairs and Spatial Planning was not running as it should. If the authority of spatial planning is centralized to the central government, as stated in the Job Creation Bill, it is feared that the misuse of spatial use in the regions will increase. Likewise, the occurrence of the flood as a result of increased environmental damage due to spatial use that is not following its designation and function. Therefore, it is necessary to review again the plan to revoke the authority of spatial planning at the regency/city level and the provincial government level in the Job Creation Bill.
\end{abstract}

Keywords: flood disasters; Job Creation Bill; spatial use management; Spatial Planning Law

Abstrak: Banjir hampir terjadi di sebagian besar wilayah Indonesia, termasuk di Bengkulu.
Penyebab banjir di Bengkulu lebih dikarenakan faktor perilaku manusia, yaitu alih fungsi lahan
yang masif. Padahal Undang-Undang tentang Penataan Ruang (UU Penataan Ruang) sudah
mengatur bagaimana pemanfaatan ruang seharusnya dilakukan dan bagaimana pengendaliannya.
Di sisi lain, saat ini pemerintah berencana akan mengubah aturan mengenai penataan ruang ini
untuk mempermudah perizinan dalam investasi melalui RUU tentang Cipta Kerja. RUU mengatur
kewenangan penataan ruang merupakan kewenangan pemerintah pusat. Permasalahannya
adalah bagaimana pengawasan dan pengendalian pemanfaatan ruang dilakukan di Bengkulu
dan bagaimana dengan pengawasan pengendalian pemanfaatan ruang nantinya jika kewenangan
penataan ruang dipusatkan di pemerintah pusat? Studi literatur digunakan untuk mengkaji dan
hasil kajian menunjukkan bahwa pemerintah pusat maupun Pemerintah Daerah Provinsi Bengkulu
belum melakukan pengawasan dan pengendalian pemanfaatan ruang sebagaimana yang diatur
dalam UU Penataan Ruang. Terbukti hanya melakukan review RTRW Provinsi Bengkulu tanpa
melakukan penegakan hukum atas pelanggaran pemanfaatan ruang. Di sisi lain, audit tata ruang 
yang dilakukan Kementerian ATR/BPN tidak berjalan sebagaimana mestinya. Jika kewenangan penataan ruang dipusatkan ke pemerintah pusat, sebagaimana disebutkan dalam RUU Cipta Kerja, dikhawatirkan penyalahgunaan pemanfaatan ruang di daerah semakin meningkat. Demikian juga dengan kejadian banjir sebagai dampak dari meningkatnya kerusakan lingkungan akibat pemanfaatan ruang yang tidak sesuai peruntukan dan fungsinya. Oleh karena itu, perlu kiranya ditinjau kembali mengenai rencana mencabut kewenangan penataan ruang di tingkat kabupaten/ kota dan di tingkat pemerintah provinsi dalam RUU Cipta Kerja.

Kata Kunci: bencana banjir; pengendalian pemanfaatan ruang; RUU Cipta Kerja; UU Penataan Ruang

\section{Pendahuluan}

Badan Nasional Penanggulangan Bencana (BNPB) mencatat sepanjang tahun 2019 telah terjadi 3.814 kejadian dengan 784 di antaranya merupakan bencana banjir (BNPB, 2020a). Banjir terjadi hampir di sebagian besar wilayah Indonesia. Bahkan beberapa wilayahyang dulunya bukan merupakan kawasan rawan banjir, di tahun 2019 mengalami banjir besar, seperti yang terjadi di Provinsi Bengkulu, banjir melanda di sembilan kabupaten/kota. Data BNPB menyebutkan bahwa bencana banjir tersebut telah mengakibatkan 30 orang meninggal dunia, 12.000 warga harus mengungsi, 6 orang dinyatakan hilang, 4 orang luka-luka, 13.000 jiwa terdampak, 1.225 rumah rusak, 1.187 unit rumah terendam, 7 fasilitas pendidikan rusak ringan, 7 fasilitas pendidikan terendam lumpur, 40 titik infrastruktur terendam, 9 unit sarpras perikanan dan kelautan rusak, 3.000 hektar sawah dan kebun rusak, dan 857 hewan ternak mati (BNPB, 2019).

Banjir adalah salah satu bentuk bencana di Indonesia yang terjadi hampir setiap tahun. Dalam 10 tahun terakhir, bencana banjir selalu menempati posisi pertama kejadian bencana (Tabel 1). Bahkan dalam buku Indonesia Disaster Management Reference Handbook bencana banjir terbesar pernah terjadi di Indonesia, yaitu pada bulan Mei-Juli 2016. Banjir terjadi di Kalimantan Selatan, Kalimantan Barat, Kalimantan Tengah, Bengkulu, Gorontalo, Jawa Barat, Jawa Tengah, Bali, Nusa Tenggara Timur, Sulawesi Utara, dan Papua. Kemudian di bulan Agustus-Oktober 2016 banjir besar kembali melanda Nusa Tenggara Timur, Jawa Timur, Jawa Barat, Jawa Tengah, Aceh, Sumatera Utara, Sulawesi Selatan, dan Jambi (Center for Excellence in Disaster Management \& Humanitarian Assistance, 2018: 19-20). Akibat banjir 2016, sebanyak 250 orang meninggal, 1.413 orang luka-luka, 2.916.688 orang terdampak, 3.264 unit rumah rusak berat, 3.467 unit rumah rusak sedang, 8.141 unit rumah rusak ringan, 334.017 unit rumah terendam, 92 unit fasilitas kesehatan rusak, 281 unit fasilitas peribadatan rusak, dan 1.137 unit fasilitas pendidikan rusak (BNPB, 2020b).

Tabel 1.

Jumlah Kejadian Bencana di Indonesia Berdasarkan Jenis Bencana, Tahun 2020

\begin{tabular}{clc}
\hline No & \multicolumn{1}{c}{ Jenis Bencana } & $\begin{array}{c}\text { Jumlah } \\
\text { Kejadian }\end{array}$ \\
\hline 1. & Banjir & 6.548 \\
2. & Puting beliung & 5.437 \\
3. & Tanah longsor & 4.337 \\
4. & Kebakaran hutan dan lahan & 894 \\
5. & Kekeringan & 754 \\
6. & Gelombang pasang/abrasi & 188 \\
7. & Gempa bumi & 159 \\
8. & Letusan gunung api & 106 \\
9. & Tsunami & 9 \\
10. & Gempa bumi dan tsunami & 2 \\
\hline
\end{tabular}

Sumber: BNPB, 2020c

Banyak kalangan menyatakan bahwa banjir di Indonesia terjadi karena adanya penyalahgunaan tata ruang. Salah satunya adalah dari Direktorat Jenderal Tata Ruang Kementerian Agraria dan Tata Ruang/Badan Pertanahan Nasional (ATR/BPN) yang menemukan ketidaksesuaian pemanfaatan ruang, di antaranya di kawasan sempadan sungai dan pantai, di kawasan pertanian, hutan lindung, dan ruang terbuka hijau (RTH) di tiga kabupaten/kota Kabupaten Takalar sehingga menyebabkan banjir di Kota Makassar, Kabupaten Gowa pada Januari 2019 (Hutapea, 2019). Demikian juga dengan banjir Bengkulu, yang menurut evaluasi Gubernur Bengkulu dan BNPB, terjadi akibat rusaknya kawasan hulu sungai, daerah aliran sungai (DAS), daerah hilir 
sungai, dan daerah resapan air. Diperkirakan telah terjadi perubahan fungsi lahan yang tidak sesuai dengan peruntukannya berdasarkan Rencana Tata Ruang Wilayah (RTRW) Provinsi Bengkulu (Firmansyah, 2019).

Padahal pemanfaatan ruangdi Indonesia harus didasarkan pada RTRW yang dalam penyusunannya mengacu pada Undang-Undang Nomor 26 Tahun 2007 tentang Penataan Ruang (UU Penataan Ruang). UU tersebut mengatur bahwa penataan ruang merupakan suatu sistem proses perencanaan tata ruang, pemanfaatan ruang, dan pengendalian pemanfaatan ruang. Tujuan dari penataan ruang ini adalah untuk mewujudkan ruang wilayah nasional yang aman, nyaman, produktif, dan berkelanjutan dengan: (1) Terwujudnya keharmonisan antara lingkungan alam dan lingkungan buatan; (2) Terwujudnya keterpaduan dalam penggunaan sumber daya alam dan sumber daya buatan dengan memperhatikan sumber daya manusia; dan (3) Terwujudnya pelindungan fungsi ruang dan pencegahan dampak negatif terhadap lingkungan akibat pemanfaatan ruang.

Jika mengacu pada UU Penataan Ruang tersebut, maka seharusnya bencana banjir tidak terjadi. Banjir terjadi ketika ruang untuk meresapnya air limpasan hujan berkurang atau tidak ada lagi sehingga sungai tidak lagi mampu menampung air limpasan hujan dan menggenangi berbagai wilayah seperti permukiman, jalan, dan berbagai tempat yang bukan tempatnya air seharusnya mengalir. Jika dilihat dari tujuan penataan ruang terlihat bahwa munculnya banjir di berbagai wilayah terjadi karena adanya ketidakharmonisan antara lingkungan alam dengan lingkungan buatan sehingga pelindungan fungsi ruang dan pencegahan dampak negatif terhadap lingkungan akibat pemanfaatan ruang tidak terwujud.

Banyak penelitian memperlihatkan adanya pengaruh perubahan tata guna lahan dengan peningkatan debit banjir, antara lain: penelitian Halim (2014) pada DAS Sungai Malalayang, penelitian Warsilan (2019) tentang perubahan penggunaan lahan di Kota Samarinda, dan penelitian Nurhamidah, Junaidi, dan Kurniawan (2018) terhadap perubahan tata guna lahan di DAS Batang Arau Padang. Keseluruhan penelitian menunjukkan bahwa berkurangnya daerah resapan air karena perubahan tata guna lahan telah berpengaruh terhadap meningkatnya kejadian banjir. Oleh karena itu, pengendalian perubahan tata guna lahan diperlukan.

Pengaturan pengendalian tata guna lahan dicantumkan dalam UU Penataan Ruang. Pengawasan atas pengendalian pemanfaatan ruang menjadi kewenangan pemerintah pusat dan pemerintah daerah (provinsi dan kabupaten/kota). Namun, dalam RUU Cipta Kerja, kewenangan pengendalian pemanfaatan ruang akan dialihkan kepada pemerintah pusat melalui RUU Cipta Kerja. Permasalahannya adalah bagaimana pengawasan dan pengendalian pemanfaatan ruang selama ini, khususnya di Bengkulu, mengacu UU Penataan Ruang? Bagaimana jika kewenangan pengawasan dan pengendalian pemanfaatan ruang ditarik ke pemerintah pusat seperti yang direncanakan dalam RUU Cipta Kerja?

Tulisan ini akan mengkaji pengawasan dan pengendalian terhadap penyalahgunaan ruang di daerah Bengkulu dari sisi regulasi yang ada, yaitu UU Penataan Ruang dan dalam RUU Cipta Kerja. Penulis akan menggunakan kasus Bengkulu sebagai contoh kasus bagaimana pengawasan dan pengendalian pemanfaatan ruang yang ada di daerah tersebut yang telah berdampak pada terjadinya bencana banjir. Kajian ini dilakukan dengan menggunakan metode penelitian kepustakaan (library research), yaitu penelitian yang data-datanya dalam berbagai material berasal dari perpustakaan, baik berupa buku, ensiklopedi, kamus, jurnal, dokumen, majalah, dan lain sebagainya (Hadi, 1990 dalam Harahap, 2014; Mardalis, 1999 dalam Mirzaqon \& Purwoko, 2018). Atau dengan kata lain, penelitian kepustakaan merupakan penelitian yang membatasi kegiatannya hanya pada bahan-bahan koleksi perpustakaan saja tanpa memerlukan riset lapangan (Zed, 2008: 1)

Penelusuran kepustakaan dalam tulisan ini dilakukan untuk mengetahui apa itu banjir, banjir sebagai bencana, penyebab banjir, regulasi tentang pengendalian banjir, serta pengawasan dan pengendalian pemanfaatan ruang, hasil-hasil penelitian sebelumnya, data publikasi dari BNPB mengenai banjir, dan berita dari media massa sebagai data primer untuk memperkuat analisis 
dalam tulisan ini. Pertimbangan penggunaan berita media massa baik cetak maupun online sebagai sumber data primer, dengan asumsi media massa memberikan fakta riil di lapangan sebagaimana diyakini pendekatan positivisme yang menyatakan bahwa media merupakan saluran pesan (Eriyanto, 2009: 25). Analisis dilakukan dengan teknik analisis isi, yaitu dengan membahas secara mendalam terhadap isi dari suatu informasi. Analisis isi menitikberatkan pada analisis atau interpretasi bahan tertulis berdasarkan konteksnya (Bungin, 2006: 175).

Penelitian terkait masalah banjir dan perubahan tata guna lahan sudah banyak dilakukan. Seperti penelitian Arief Rosyidie (2013: 241-249) yang menyatakan bahwa perubahan tata ruang atau tata guna lahan lebih banyak berkontribusi terhadap terjadinya banjir dibandingkan dengan pembangunan fisik pengendali banjir. Namun, penelitian Rosyidie tidak menyentuh pada bagaimana pengawasan dan pengendalian pemanfaatan ruang dilakukan. Pada penelitian Iswandi Umar dan Indang Dewata (2018: 251-257) juga menunjukkan bahwa selain tingginya intensitas curah hujan, konversi kawasan hutan menjadi penggunaan lain menjadi penyebab banjir. Penelitian Umar dan Dewata juga tidak menyentuh pengawasan dan pengendalian pemanfaatan ruang. Oleh karenanya, kajian terhadap pengawasan dan pengendalian pemanfaatan ruang keterkaitannya dengan bencana banjir perlu dilakukan. Apalagi dengan rencana untuk menarik kewenangan pengawasan dan pengendalian pemanfaatan ruang ke Pemerintah Pusat sebagaimana tertuang dalam RUU Cipta Kerja, kajian ini menjadi menarik untuk dilakukan.

\section{Banjir sebagai Bencana}

Banjir didefinisikan sebagai massa air yang diproduksi dari limpasan air di permukaan tanah yang relatif tinggi dan tidak dapat ditampung yang meluap secara alami serta menimbulkan genangan (Ward, 1978). Namun, banjir bisa menjadi bencana. Menurut UU Nomor 24 Tahun 2007 tentang Penanggulangan Bencana (UU Penanggulangan Bencana), bencana adalah:

"peristiwa atau rangkaian peristiwa yang mengancam dan mengganggu kehidupan dan penghidupan masyarakat yang disebabkan, baik oleh faktor alam dan/atau faktor nonalam maupun faktor manusia sehingga mengakibatkan timbulnya korban jiwa manusia, kerusakan lingkungan, kerugian harta benda, dan dampak psikologis" (Pasal 1 angka 1 UU Penanggulangan Bencana).

Mengacu pada definisi tersebut, maka banjir menjadi bencana ketika banjir tersebut telah menimbulkan kerugian harta benda, kerusakan lingkungan, serta mengancam dan mengganggu penghidupan masyarakat. Kejadian banjir di Indonesia sudah mengarah pada banjir sebagai bencana karena telah menimbulkan kerugian harta, benda, bahkan jiwa.

Menurut Nurjanah, Dede, dan Adikoesoemo (2012: 14) dan Mayunga (2008, dalam Rijanta, Hizbaron, \& Baiquni, 2014: 9-10) bencana terjadi karena potensi bahaya (ancaman) bertemu dengan kerentanan, serta adanya faktor pemicu seperti digambarkan pada Bagan 1. Akibat adanya potensi bahaya yang bertemu dengan elemen kerentanan sehingga kerugian, kehilangan, dan kerusakan tidak mungkin dihindarkan lagi, maka suatu kondisi bencana terjadi.

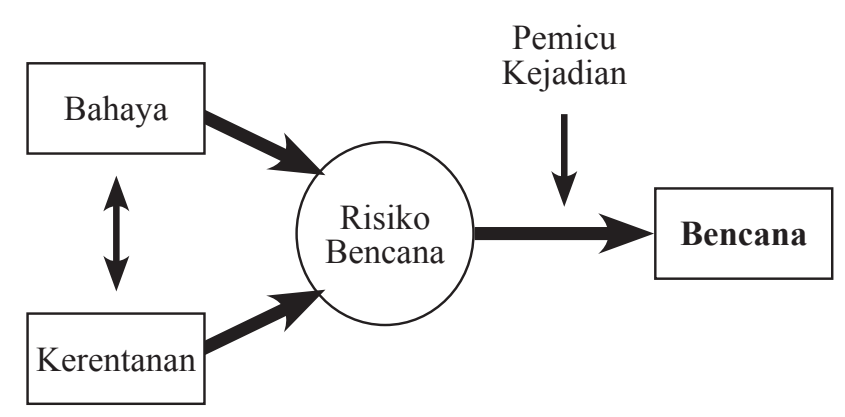

Bagan 1. Proses Terjadinya Bencana

Sumber: Nurjanah, Dede, \& Adikoesoemo, 2012: 14

Bahaya adalah suatu fenomena alam atau buatan yang mempunyai potensi mengancam kehidupan manusia, kerugian harta benda dan kerusakan lingkungan (Nurjanah, Dede, \& Adikoesoemo, 2012: 15). Ada lima kelompok bahaya menurut United Nations - International Strategy for Disaster Reduction/UNISDR, yaitu dari aspek geologi, hidrometeorologi, biologi, teknologi, dan lingkungan. Banjir termasuk dalam kelompok bahaya dari aspek hidrometeorologi (Triutomo, Widjaya, \& Amri, 2007:8). Kerentanan merupakan suatu kondisi masyarakat 
yang mengarah pada ketidakmampuan dalam menghadapi ancaman bencana. Ketika banjir sudah menjadi bencana, masyarakat atau manusia yang terkena dampaknya oleh peristiwa tersebut tidak mampu untuk menanggulanginya.

Ada tiga faktor yang menyebabkan bencana banjir (Yulaelawati \& Shihab, 2008: 8-11) yaitu: Pertama, faktor aktivitas manusia, seperti pemanfaatan dataran banjir untuk pemukiman dan industri, penggundulan hutan dan kemudian mengurangi resapan pada tanah dan meningkatkan larian tanah permukaan. Erosi yang terjadi dapat mengakibatkan sedimentasi di terusan-terusan sungai yang kemudian mengganggu jalannya air. Aktivitas manusia lainnya yang dapat menyebabkan banjir adalah adanya pemukiman di dataran banjir, pembangunan di daerah dataran banjir dengan mengubah saluran-saluran air yang tidak direncanakan dengan baik, dan adanya perilaku membuang sampah sembarangan yang akan menyumbat saluran-saluran air yang ada. Bahkan terkadang alur sungai diurug untuk dijadikan permukiman. Akibatnya aliran sungai saat musim hujan menjadi tidak lancar dan menimbulkan banjir. Kedua, faktor alam yang bersifat tetap (statis) seperti kondisi geografi yang berada pada daerah yang sering terkena badai atau siklon, kondisi topografi yang cekung yang merupakan dataran banjir, kondisi alur sungai yang kemiringan dasar sungainya datar. Ketiga, faktor alam yang bersifat dinamis seperti curah hujan yang tinggi, terjadinya pembendungan atau arus balik yang sering terjadi di muara sungai atau pertemuan sungai besar, penurunan muka tanah atau amblesan, pendangkalan dasar sungai karena sedimentasi yang cukup tinggi.

Aktivitas manusia berperan besar bagi terjadinya bencana banjir. Seperti bencana banjir dan tanah longsor yang terjadi di Bengkulu. Menurut Kepala Pusat Data dan Informasi dan Humas BNPB, banjir di Bengkulu disebabkan oleh adanya kerusakan lingkungan di daerah hulu akibat aktivitas pertambangan, perkebunan, dan pembangunan pemukiman. Alih fungsi lahan kawasan hulu dari hutan menjadi perkebunan, kawasan tambang, dan pemukiman menjadi faktor penyebab terjadinya banjir di Bengkulu, selain curah hujan yang ekstrim (Ronald, 2019). Menurut Gubernur Bengkulu, banjir yang terjadi tidak hanya akibat alih fungsi lahan di kawasan hulu sungai. Akan tetapi, juga dikarenakan tiga penyebab lainnya, yaitu: (1) Penyempitan badan sungai, terutama di Kota Bengkulu; (2) Pendangkalan di daerah hilir akibat sedimentasi dan penumpukan sampah; dan (3) Berkurangnya daerah resapan air (catchment area) (Firmansyah \& Halim, 2019).

Rusaknya kawasan hulu di Bengkulu dapat dilihat dari hasil penelitian Wiryono, Senoaji, dan Fajrin (2015) yang menyatakan bahwa DAS Bengkulu yang masuk wilayah Bengkulu Tengah seluas $34,67 \%$ luasannya telah menjadi lahan pertanian, dan $21,51 \%$ lainnya menjadi areal pertambangan dan penggalian. Analisis Global Forest Watch (GFW) telah terjadi penurunan tutupan lahan berpohon di DAS Bengkulu seluas 11.400 hektar selama periode 2001-2018 (Sulaeman, Pradana, \& Hamzah, 2019). Kemudian, penelitian Hindarto, Hidayat, dan Depari (2013) memperlihatkan tutupan lahan di DAS Lemau hanya tersisa 15.368,5 hektar (29,8\%). Tutupan lahan berpohon yang demikian sedikit mengakibatkan resapan air di DAS Bengkulu atau pun DAS Lemau sangat minim. Hal ini tentunya akan berkontribusi terjadinya longsor dan banjir ketika curah hujan tinggi. Sementara itu, rusaknya kawasan tengah DAS Bengkulu dapat dilihat dari hasil penelitian Wiryono, Senoaji, \& Fajrin (2015) yang menyatakan bahwa sekitar 35,94\% DAS Bengkulu yang ada di Kota Bengkulu telah difungsikanuntuk sektorperdagangan, perhotelan, dan restoran; dan 23,58\% digunakan untuk jasa lain. Menyempitnya badan sungai akibat dialihfungsikannya sempadan dan badan sungai untuk penggunaan lain tersebut menyebabkan badan sungai tidak mampu lagi menampung run off ketika curah hujan tinggi terjadi. Kondisi ini diperparah dengan buruknya pengelolaan sampah dan sikap kepedulian masyarakat untuk mengelola sampahnya yang rendah. Buruknya pengelolaan sampah menjadi permasalahan yang tidak kunjung selesai hingga saat ini di Kota Bengkulu (Faisal, 2020). Di sisi lain, sikap dan tindakan masyarakat dalam pengelolaan sampah rumah tangga di Kota Bengkulu juga masih rendah, seperti dikemukakan Ramon dan Afriyanto (2015) dalam penelitiannya. 
Rusaknya daerah hulu dan tengah DAS di Bengkulu telah menyebabkan sedimentasi DAS bagian hilir. Penelitian Satmaidi, Muthia, dan Wulandari (2018) menemukan sedimentasi di bagian hilir DAS Bengkulu disebabkan adanya kegiatan penambangan batu bara di hulu DAS. Limbah pencucian batu bara yang mengandung belerang dan merkuri mengalir di sepanjang sungai hingga ke hilir DAS Bengkulu, bahkan hingga ke laut. Dalam penelitian Edriani (2014) dinyatakan di wilayah sub-DAS Bengkulu bagian hilir tidak terdapat kawasan hutan lindung sama sekali. Kondisi ini menjadikan kawasan hilir DAS Bengkulu rawan erosi dan limbah pertambangan serta sampah dari hulu DAS terus mengalir hingga ke laut.

Berbagai faktor penyebab di atas jika mengacu pendapat Yulaelawati \& Shihab (2008: 8-11), maka penyebab banjir di Bengkulu lebih disebabkan oleh faktor manusia, yaitu aktivitas manusia baik di kawasan hulu, tengah, ataupun hilir. Di kawasan hulu, banjir terjadi sebagai akibat aktivitas manusia dengan mengalihfungsikan lahan hutan menjadi kawasan pertambangan, perkebunan, dan permukiman. Di kawasan tengah, banjir terjadi akibat aktivitas manusia dengan mengalihfungsikan sempadan sungai menjadi kawasan perdagangan, perhotelan, dan jasa. Di kawasan hilir DAS Bengkulu, kawasan lindung tidak ada. Akibatnya, ketika terjadi banjir dari hulu, air akan mengalir ke laut tanpa ada yang menghalangi. Begitu pun sebaliknya, ketika air pasang naik, banjir rob terjadi tanpa ada yang melindungi daratan.

Pada dasarnya pengendalian banjir sudah dilakukan dengan mengacu pada UU Nomor 17 Tahun 2019 tentang Sumber Daya Air (UU Sumber Daya Air). Konsepnya pengendalian banjir dilakukan melalui kegiatan pencegahan, penanganan saat banjir, dan pemulihan pascabanjir sebagaimana yang dikemukakan Stephen Bieri (tt: 5-6). Kemudian dalam Peraturan Pemerintah Nomor 38 Tahun 2011 tentang Sungai (PP Sungai), khususnya pada Bagian Keempat Pengendalian Daya Rusak Air Sungai, upaya untuk mengurangi risiko banjir, dilakukan melalui pengelolaan risiko banjir, baik dari sisi pengurangan risiko besaran banjir maupun dari sisi pengurangan risiko kerentanan banjir.
Di sinilah upaya struktural dan nonstruktural dilakukan. Pengurangan risiko besaran banjir dilakukan melalui pembangunan prasarana pengendali banjir (peningkatan kapasitas sungai, tanggul, pompa air, bendungan, perbaikan drainase kota) dan prasarana pengendali aliran permukaan (resapan air dan penampung banjir). Sementara itu, upaya pengurangan risiko kerentanan banjir dilakukan dengan penetapan batas dataran banjir, penetapan zona peruntukan lahan sesuai risiko banjir, pengawasan peruntukan lahan di dataran banjir, persiapan menghadapi banjir, penanggulangan banjir dan pemulihan setelah banjir. Penetapan zona peruntukan lahan sesuai risiko banjir ini dituangkan dalam peta zonasi peruntukan lahan dataran banjir, yang ditetapkan oleh bupati/walikota. Bupati/walikota mempunyai kewajiban untuk melakukan pengawasan terhadap zona peruntukan lahan sesuai risiko banjir yang sudah ditetapkan. Bahkan pemanfaatan bantaran dan sempadan sungai, perlu mendapatkan izin dari menteri, gubernur, atau bupati/walikota sesuai dengan kewenangannya. Semua ketentuan ini sudah diatur dalam Pasal 34 s.d. Pasal 48 dan Pasal 57 dan Pasal 58 PP Sungai. Dalam praktiknya, berbagai ketentuan dalam regulasi tersebut banyak yang dilanggar. Meskipun penetapan batas banjir dan zona peruntukan lahan sesuai risiko banjir sudah dilakukan. Kelemahannya adalah pada pengawasan pemanfaatan lahan sesuai peruntukannya seperti yang diatur dalam UU Penataan Ruang.

\section{Pemanfaatan Lahan}

Pemanfaatan lahan pada hakikatnya merupakan pemanfaatan ruang yang telah diatur dalam UU Penataan Ruang. Berdasarkan UU tersebut, pemanfaatan ruang merupakan upaya untuk mewujudkan struktur ruang dan pola ruang sesuai dengan rencana tata ruang melalui penyusunan dan pelaksanaan program beserta pembiayaannya. Pemanfaatan ruang harus mengacu pada fungsi ruang yang sudah ditetapkan dalam rencana tata ruang, yaitu sebagai kawasan lindung atau pun sebagai kawasan budi daya. Masing-masing mempunyai fungsi yang berbeda. Kawasan lindung mempunyai fungsi utama melindungi kelestarian lingkungan hidup 
yang mencakup sumber daya alam dan sumber daya buatan. Sementara itu, kawasan budi daya mempunyai fungsi utama untuk dibudidayakan atas dasar kondisi dan potensi sumber daya alam, sumber daya manusia, dan sumber daya buatan.

Dalam Rencana Tata Ruang Wilayah Nasional sebagaimana yang diatur dalam PP Nomor 26 Tahun 2008 tentang Rencana Tata Ruang Wilayah Nasional juncto PP Nomor 13 Tahun 2017 tentang Perubahan atas PP Nomor 26 Tahun 2008, sudah ditentukan luas minimal dari setiap pulau. Untuk Pulau Sumatera luas minimal kawasan lindung adalah 40\%, Pulau Jawa 30\%, Pulau Kalimantan 45\%, Pulau Sulawesi 40\%, Pulau Papua 70\%, Kepulauan Maluku 30\%, dan Kepulauan Nusa Tenggara 30\% dari luas pulau masing-masing sesuai dengan kondisi, karakter, dan fungsi ekosistem serta tersebar secara proporsional. Selain itu, untuk kawasan budi daya paling tidak 30\% dari luas kawasan perkotaan merupakan ruang terbuka hijau (RTH).

Namun, pada kenyataannya luasan kawasan lindung beberapa pulau di wilayah Indonesia berada jauh dari yang seharusnya. Berdasarkan data Kementerian Lingkungan Hidup dan Kehutanan (KLHK), di tahun 2017 tutupan lahan berhutan di Pulau Sumatera tinggal 25,7\%, Pulau Jawa 16,4\%, Kalimantan 46,0\%, Sulawesi 45,5\%, Bali Nusa Tenggara 23,4\%, Maluku 61,5\%, dan Papua 79,2\% (KLHK, 2018: 6). Luasan tutupan lahan berhutan di Pulau Jawa, Sumatera dan Bali-Nusa Tenggara jauh dari yang seharusnya (Tabel 2). Demikian juga RTH di kabupaten/kota di ketiga pulau tersebut. Banyak daerah yang realisasi RTH-nya tidak sesuai dengan rancangan yang ada di RTRW-nya. Kondisi ini berpengaruh terhadap munculnya kejadian banjir di wilayahwilayah tersebut. Berdasarkan data BNPB kejadian banjir tertinggi terjadi di Pulau Jawa, kemudian menyusul Pulau Sumatera (Tabel 2).

Tabel 2.

Luasan Tutupan Lahan Berhutan Berdasarkan RTRW Nasional dan Data KLHK, Tahun 2017, serta Kejadian Banjir, Tahun 2010-2020***

\begin{tabular}{lcccc}
\hline Pulau & $\begin{array}{c}\text { RTRW } \\
\text { Nasional** } \\
(\mathbf{\%})\end{array}$ & $\begin{array}{c}\text { Data KLHK } \\
\mathbf{2 0 1 7 * *} \\
\mathbf{( \% )}\end{array}$ & $\begin{array}{c}\text { Keterangan } \\
\mathbf{( \% )}\end{array}$ & $\begin{array}{c}\text { Kejadian Banjir } \\
\mathbf{2 0 1 0}-\mathbf{2 0 2 0} * * *\end{array}$ \\
\hline Sumatera & 40 & 25,7 & $-14,3$ & 1.742 \\
Jawa & 30 & 16,4 & $-13,6$ & 3.217 \\
Kalimantan & 45 & 46,0 & $+1,0$ & 845 \\
Sulawesi & 40 & 45,5 & $+5,5$ & 622 \\
Bali Nusa Tenggara & 30 & 23,4 & $-6,6$ & 317 \\
Maluku & 30 & 61,5 & $+31,5$ & 106 \\
Papua & 70 & 79,2 & $+9,2$ & 88 \\
\hline
\end{tabular}

Sumber: PP 13 Tahun 2017(*), KLHK, $2018(* *)$, BNPB, 2020d, Diolah(***)

Beberapa penelitian menunjukkan adanya hubungan antara berkurangnya kawasan lindung berupa lahan dengan tutupan berhutan atau lahan dengan vegetasi kerapatan tinggi dengan bencana banjir di suatu wilayah. Banjir merupakan indikator adanya kerusakan pada DAS yang disebabkan oleh menurunnya infiltrasi akibat berkurangnya penutupan vegetasi dan ketidaksesuaian penggunaan lahan (Sinukaban, 2007, dalam Miardini, Gunawan, \& Murti, 2016). Penelitian Wardhana, Astuti, dan Kurnia (2018) di DAS Winongo, D.I. Yogyakarta membuktikannya. Hasil penelitian mereka menunjukkan konversi tutupan lahan menjadi impermeable (lahan tidak mampu menyerap air karena menjadi areal terbangun) yang terjadi di DAS Winongo setiap tahun menyebabkan meningkatnya debit banjir di kawasan tersebut. Demikian juga penelitian Nurrizqi dan Suyono (2012) dan penelitian Kirana, Hizbaron, dan Hadi (2017) yang memperlihatkan terjadinya peningkatan tren indeks banjir di Kabupaten Bandung tahun 1995-2015 seiring dengan semakin meningkatnya lahan terbangun. Wajar jika di daerah-daerah yang luas kawasan lindungnya dan RTH di kawasan budi daya tidak mencapai $30 \%$, bencana banjir kemungkinan besar akan terjadi. 
Kondisi seperti itulah yang terjadi di Provinsi Bengkulu. Perkembangan kawasan hutan provinsi Bengkulu mengalami beberapa kali perubahan luas kawasan hutan akibat perubahan fungsi maupun peruntukan. Mengacu kepada Perda Provinsi Bengkulu Nomor 305 Tahun 1998 tentang Pemaduserasian antara Rencana Tata Ruang Wilayah Provinsi dengan Tata Guna Hutan Kesepakatan Provinsi Daerah Tingkat I Bengkulu, luas kawasan lindung yang terdiri dari kawasan konservasi dan hutan lindung adalah 1,28 juta hektar atau 64,97\% dari luas wilayah Provinsi Bengkulu. Pada tahun 2012 kawasan hutan provinsi Bengkulu berkurang. Berdasarkan Keputusan Menteri Kehutanan Nomor 784/ Menhut-II/2012 tanggal 27 Desember 2012, luas kawasan hutan provinsi Bengkulu menjadi 924.631 hektar atau 46,72\% dari luas wilayah Provinsi Bengkulu.

Kawasan lindung yang ada mengalami perubahan tutupan yang cukup signifikan. Sekitar $69 \%$ cagar alam sudah tidak berhutan dan sekitar $67 \%$ taman wisata alam (TWA) sudah kehilangan tutupan hutan. Luas hutan lindung yang tidak lagi berhutan mencapai hampir $25 \%$. Hutan produksi yang masih berupa hutan primer tinggal $13 \%$ dan hutan sekunder $52 \%$. Hutan produksi terbatas $50 \%$ telah kehilangan tutupan lahan yang berhutan, menyisakan 10\% berupa hutan primer dan $40 \%$ hutan sekunder. Keberadaan kawasan hutan di Provinsi Bengkulu ini terancam oleh adanya kegiatan perambahan, penebangan liar, dan beroperasinya beberapa perusahaan besar non-kehutanan (seperti perkebunan sawit dan pertambangan) (Dinas Lingkungan Hidup dan Kehutanan Provinsi Bengkulu, 2017: 27-30). Berdasarkan data Direktorat Inventarisasi dan Pemantauan Sumber Daya Hutan Direktorat Jenderal Planologi Kehutanan dan Tata Lingkungan KLHK, luas tutupan lahan berhutan di Provinsi Bengkulu per 2018 tinggal 647,6 ribu hektar $(32,2 \%$ dari luas wilayah provinsi Bengkulu) (KLHK, 2019a: 19) dengan kondisi lahan kritis mencapai 120.598 hektar dan lahan sangat kritis 28.289 hektar (KLHK, 2019b: 113).

Rusaknya kawasan hulu sungai di Provinsi Bengkulu merupakan akibat beralih fungsinya peruntukan lahan tidak sesuai dengan RTRW Provinsi Bengkulu. Beralih fungsinya kawasan lindung menjadi perkebunan atau pertambangan inilah yang menjadi penyebab terjadinya banjir di Provinsi Bengkulu (Firmansyah, 2019). Tidak hanya itu, beberapa kabupaten/kota di Provinsi Bengkulu RTH-nya tidak mencapai 30\% sesuai ketentuan UU Penataan Ruang. Seperti dikemukakan dalam penelitian Sandi, Iskandar, dan Komar (2017), RTH Kota Bengkulu hanya 19,6\% dari wilayahnya. Luas RTH tersebut tidak sesuai dengan RTRW Kota Bengkulu 20122032 yang tertuang dalam Peraturan Daerah Kota Bengkulu Nomor 14 Tahun 2012 tentang Rencana Tata Ruang Wilayah Kota Bengkulu Tahun 2012-2032. Demikian juga RTH di Kabupaten Bengkulu Selatan yang berdasarkan hasil penelitian Sitorus, Mustamei, dan Mulya (2019) hanya 19,2\% dari wilayahnya.

Terus menurunnya luas kawasan lindung dan RTH di Provinsi Bengkulu dengan kondisi lahan kritis yang cukup luas telah berdampak terhadap meningkatnya kejadian banjir di Provinsi Bengkulu. Data BNPB menunjukkan adanya tren meningkatnya kejadian banjir di Provinsi Bengkulu dalam 10 tahun terakhir (Tabel 3). Kejadian banjir terbanyak dan terparah adalah di tahun 2015 dan 2019.

Tabel 3.

Tren Kejadian Banjir di Provinsi Bengkulu, Tahun 2010-2019

\begin{tabular}{ccc}
\hline Tahun & $\begin{array}{c}\text { Kejadian } \\
\text { Banjir }\end{array}$ & $\begin{array}{c}\text { Total } \\
\text { Kejadian } \\
\text { Bencana }\end{array}$ \\
\hline 2010 & 3 & 3 \\
2011 & 3 & 10 \\
2012 & 4 & 8 \\
2013 & 8 & 15 \\
2014 & 9 & 14 \\
2015 & 12 & 31 \\
2016 & 5 & 19 \\
2017 & 3 & 8 \\
2018 & 3 & 7 \\
2019 & 16 & 18 \\
\hline
\end{tabular}

Sumber: BNPB, 2020e, Diolah

Menurut Rustiadi, Saefulhakim, dan Panuju (2009: xxiv), di Indonesia banyak terjadi pemanfaatan ruang yang tidak sesuai dengan peruntukannya atau fungsi ruangnya. Hal ini terjadi karena pemanfaatan ruang di Indonesia dihadapkan pada permasalahan: (1) Adanya peningkatan peran dan otoritas 
pemerintah daerah (pemda) atau elite daerah seiring dengan berubahnya sistem pemerintahan dari sentralisasi menjadi desentralisasi; (2) Perencanaan pembangunan belum banyak mengubah struktur ketimpangan wilayah dan telah memacu laju degradasi lingkungan serta memperlemah kohesi sosial; (3) Peningkatan kebutuhan pengembangan wilayah sering kali mengabaikan isu ekologi dan sektor publik untuk berpartisipasi dalam perencanaan. Bahkan Rydin (1993, dalam Rustiadi, Saefulhakim, \& Panuju, 2009) menyatakan perencanaan wilayah saat ini dibentuk oleh anarki pasar.

Penyimpangan pemanfaatan ruang terjadi juga di Provinsi Bengkulu. Contoh penyimpangan ruang terjadi TWA Pantai Panjang yang merupakan kawasan lindung. Berdasarkan Peraturan Daerah Provinsi Bengkulu Nomor 2 Tahun 2012 tentang Rencana Tata Ruang Wilayah Provinsi Bengkulu Tahun 2012-2023 pembangunan Pembangkit Listrik Tenaga Uap (PLTU) akan dilakukan di Napal Putih. Akan tetapi dalam pelaksanaannya PLTU dibangun di TWA Pantai Panjang (Frastien, Iskandar, \& Satmaidi, 2018; Supardi, 2019). Penyimpangan pemanfaatan ruang juga terjadi di Kawasan Danau Dusun Besar yang seharusnya merupakan lahan sawah beririgasi teknis. Kawasan tersebut telah beralih fungsi menjadi pemukiman, sarang walet, dan perkebunan sawit (Alimansyah, 2011).

\section{Pengawasan dan Pengendalian Pemanfaatan Ruang}

Pemanfaatan ruang di Indonesia mengacu pada UU Penataan Ruang, yaitu harus sesuai dengan fungsi ruang yang sudah ditetapkan dalam rencana tata ruang. Tujuannya agar terwujud keharmonisan antara lingkungan alam dan lingkungan buatan, keterpaduan dalam penggunaan sumber daya alam dan sumber daya buatan dengan memperhatikan sumber daya manusia, serta terlindunginya fungsi ruang untuk mencegah dampak negatif terhadap lingkungan akibat pemanfaatan ruang. Mengingat Indonesia adalah negara yang rawan bencana, maka dalam UU Penataan Ruang diatur juga bagaimana pengendalian pemanfaatan ruang dilakukan, yaitu melalui penetapan peraturan zonasi, perizinan, pemberian insentif dan disinsentif, serta pengenaan sanksi. Arah kebijakannya bahwa setiap ruang pemanfaatannya didasarkan pada pedoman zonasi yang sudah ditetapkan oleh pemerintah dan pemda. Sementara itu, pemanfaatannya harus dengan izin dari pemerintah dan pemda sesuai dengan kewenangannya. Apabila pemanfaatan ruang tidak sesuai dengan rencana ruang atau izin pemanfaatan yang sudah diberikan akan diberikan sanksi. Bentuk sanksinya pun bermacam-macam, mulai dari peringatan tertulis, penghentian sementara kegiatan, penutupan lokasi, pencabutan izin, pembatalan izin, pembongkaran bangunan, pemulihan fungsi ruang, ataupun denda administratif. Semua itu tertuang dalam PP Nomor 15 Tahun 2010 tentang Penyelenggaraan Penataan Ruang. Pemda (provinsi maupun kabupaten/kota) mempunyai kewenangan untuk melakukan pengawasan atas pemanfaatan ruang di wilayahnya tersebut.

Praktiknya, pengawasan dan pengendalian pemanfaatan ruang tidak berjalan sebagaimana mestinya. Contoh kasus pemanfaatan ruang di TWA Pantai Panjang Bengkulu. Kawasan tersebut berdasarkan Perda Provinsi Bengkulu Nomor 2 Tahun 2012 merupakan kawasan lindung. Namun, dalam kawasan tersebut dibangun lapangan golf oleh BUMD Bengkulu Mandiri, kolam pemancingan oleh Pemda Provinsi Bengkulu, menjadi areal kerja wilayah PT. Pelindo II, lapangan tembak TNI AL Bengkulu, lapangan tembak Polda Bengkulu, perumahan KOREM GAMAS, perkantoran UPTD Dinas Perikanan dan Kelautan Provinsi Bengkulu, pemukiman penduduk, perkebunan warga, lokalisasi PSK, dan lokasi pembangunan PLTU (Frastien, Iskandar, \& Satmaidi, 2018). Jika mengacu pada UU Penataan Ruang, seharusnya Pemda Provinsi Bengkulu melakukan penertiban atas berbagai bangunan atau pemanfaatan ruang yang tidak sesuai peruntukan sebagai upaya pengendalian pemanfaatan ruang. Pemda Provinsi Bengkulu juga harusnya segera menyusun zonasi yang nantinya menjadi acuan dalam pemanfaatan ruang. Namun, pada kenyataannya Pemda hanya melakukan evaluasi atas pemanfaatan ruang di kawasan tersebut (Frastien, Iskandar, \& Satmaidi, 2018) dan kemudian melakukan review RTRW Provinsi. 
Dalam rangka evaluasi RTRW Provinsi Bengkulu, audit tata ruang dilakukan oleh Kementerian Agraria dan Tata Ruang/ Badan Pertanahan Nasional (Kementerian ATR/BPN). Audit tata ruang merupakan kegiatan yang dilakukan menyikapi pertumbuhan yang sangat tinggi dan tidak terkendali dalam pemanfaatan ruang di suatu wilayah. Selain itu, kegiatan ini juga merupakan alat untuk menindaklanjuti hasil pengawasan dan adanya pengaduan dari masyarakat terhadap indikasi pelanggaran pemanfaatan ruang. Melalui audit tata ruang ini akan diketahui daerah mana yang melakukan pelanggaran, dan kemudian dilakukan evaluasi bersama (Media Center Pemprov Bengkulu, 2019).

Sering kali terjadinya alih fungsi kawasan tidak sesuai peruntukan ditindaklanjuti oleh pemda dengan melakukan perubahan RTRW-nya. Hal inilah rupanya yang dilakukan oleh Pemda Provinsi Bengkulu. Saat ini Pemda Provinsi Bengkulu sedang melakukan revisi RTRW Provinsi Bengkulu dengan melakukan perubahan peruntukan dan fungsi kawasan hutan. Seperti perubahan fungsi kawasan Cagar Alam Danau Dusun Besar menjadi TWA seluas 2.067,46 hektar, Taman Buru menjadi TWA sekitar 7.271 hektar, Hutan Produksi Terbatas menjadi TWA sekitar 2.191 hektar, Hutan Lindung menjadi TWA sekitar 3.450 hektar, TWA PLG Seblat menjadi Hutan Produksi yang dapat dikonversi sekitar 246 hektar (Yusup, 2019).

Kondisi di atas memperlihatkan bahwa pengawasan atas pengendalian pemanfaatan ruang tidak berjalan sebagaimana seharusnya berdasarkan UU Penataan Ruang. Berdasarkan UU Penataan Ruang, pengendalian pemanfaatan ruang menjadi tugas dan wewenang pemda provinsi dan kabupaten/kota. Namun, belum semua daerah menyusun aturan mengenai penetapan zonasi dan insentif disinsentif. Di sisi lain, penerapan sanksi hukum atas berbagai pelanggaran dalam pemanfaatan ruang juga tidak berjalan sebagaimana mestinya. Kementerian ATR/BPN mencatat paling sedikit ada 6.621 lokasi terindikasi pelanggaran dalam pemanfaatan ruang dari tahun 2015 hingga 2018. Belum keseluruhan indikasi pelanggaran tersebut mendapatkan sanksi (Kementerian ATR/BPN, 2019).

\section{Pengendalian Pemanfaatan Ruang dalam RUU Cipta Kerja}

Saat ini pemerintah sedang berusaha untuk meningkatkan pertumbuhan ekonomi dengan memberikan iklim usaha yang kondusif bagi investasi. Hal itu dilakukan melalui upaya perubahan pengaturan yang berkaitan dengan investasi. Sulitnya memperoleh lahan dalam melakukan investasi di Indonesia, menjadi salah satu hal yang melatarbelakangi pemerintah mengajukan RUU tentang Cipta Kerja. Ada 79 UU yang diubah untuk memberikan kemudahan dalam berusaha, termasuk di dalamnya adalah UU Penataan Ruang. Perubahan UU Penataan Ruang ini terkait untuk memberikan kemudahan dalam pemberian izin lokasi (Naskah Akademik RUU Cipta Kerja, 2020: 128, 133).

Perubahan terkait UU Penataan Ruang salah satunya adalah penyederhanaan hirarki Rencana Tata Ruang. Dalam RUU Cipta Kerja, Rencana Tata Ruang Kawasan Strategis Provinsi (RTR KSP), Rencana Tata Ruang Kawasan Strategis Kabupaten/Kota (RTR KS Kab/Kota), Rencana Tata Ruang Kawasan Megapolitan (RTR Kaw Megapolitan), Rencana Tata Ruang Kawasan Perdesaan (RTR Kaw Perdesaan), dan Rencana Tata Ruang Kawasan Agropolitan (RTR Kaw Agropolitan) dihapuskan. Konsekuensi pengaturan ini adalah tidak adanya lagi kewenangan pemda provinsi dan kabupaten/ kota dalam penataan ruang. Pemda provinsi dan kabupaten/kota mempunyai tugas menyusun Rencana Rinci Tata Ruang (RRTR) dan Rencana Detail Tata Ruang (RDTR) dengan mengacu RTRW Nasional dan menetapkannya dengan peraturan daerah. Dengan catatan, apabila dalam jangka waktu 1 bulan bupati/walikota tidak menetapkan Perda mengenai RDTR ditetapkan dengan Peraturan Menteri (Naskah Akademik RUU Cipta Kerja, 2020: 150).

Dihapuskannya kewenangan pemerintah provinsi dan kabupaten/kota dalam penataan ruang menyebabkan kewenangan pengendalian pemanfaatan ruang bukan lagi wewenang pemerintah provinsi ataupun kabupaten/kota. Hal ini tentunya akan menjadi permasalahan dalam pengawasan terhadap penyalahgunaan pemanfaatan ruang di daerah. Rentang kendali yang sangat jauh ke depannya akan berpengaruh 
terhadap meningkatnya kasus penyimpangan dalam pemanfaatan ruang. Kondisi ini tentunya akan memperparah kerusakan lingkungan akibat penyimpangan pemanfaatan ruang.

Apalagi dalam RUU Cipta Kerja, ketentuan kawasan lindung minimal 30\% dari luas kawasan sebagaimana diatur dalam UU Penataan Ruang tidak ada lagi. RUU hanya mengatur penetapan luas kawasan hutan dan penutupan hutan untuk setiap pulau, DAS, provinsi, kabupaten/ kota didasarkan pada kondisi biogeofisik, iklim, penduduk, dan keadaan sosial ekonomi masyarakat setempat. Pengaturan ini tentunya cukup mengkhawatirkan bagi keberadaan kawasan lindung. Apalagi jika melihat kondisi luas kawasan lindung di beberapa pulau sudah dibawah 30\%. Oleh karena itu, perlu kiranya dipikirkan kembali mengenai ketentuan penetapan luas kawasan lindung di setiap wilayah sebagaimana diatur dalam UU Penataan Ruang, yaitu minimal $30 \%$ dari luas suatu wilayah. Untuk wilayah yang saat ini kawasan lindungnya kurang dari 30\% seharusnya didorong untuk memenuhi ketentuan tersebut dengan memperluas kawasan lindungnya.

\section{Penutup}

Banjir di Provinsi Bengkulu memperlihatkan bahwa bencana tersebut terjadi karena faktor perilaku manusia. Alih fungsi lahan di kawasan lindung, baik di hulu, tengah, maupun hilir, menjadi faktor penyebab terjadinya banjir yang trennya cenderung meningkat setiap tahun. Meskipun UU Penataan Ruang telah mengatur pengendalian pemanfaatan ruang, implementasinya tidak berjalan sebagaimana yang seharusnya. Penertiban atas berbagai pelanggaran dalam pemanfaatan ruang tidak dilakukan oleh Pemda Provinsi Bengkulu. Penyusunan zonasi dalam pemanfaatan ruang juga tidak dilakukan. Pelanggaran pemanfaatan ruang yang ditemukan melalui proses audit tata ruang yang dilakukan Kementerian ATR/BPN pun banyak yang tidak berjalan sebagaimana mestinya. Belum keseluruhan indikasi pelanggaran yang ditindak. Hal ini memperlihatkan bahwa penegakan hukum dalam pelanggaran pemanfaatan ruang masih lemah.
Alih fungsi lahan disikapi Pemda Provinsi Bengkulu dengan melakukan review RTRW Provinsi, untuk melakukan perubahan peruntukan dan fungsi kawasan hutan. Kondisi ini tentunya memprihatinkan jika mengingat meningkatnya kejadian banjir di Bengkulu terjadi karena terus berkurangnya kawasan lindung, beralih fungsinya kawasan hutan dan sempadan sungai menjadi kawasan pertambangan, perkebunan, pemukiman, perhotelan, dan perdagangan.

Di sisi lain, saat ini pemerintah berencana mengubah ketentuan dalam UU Penataan Ruang dalam RUU Cipta Kerja yang diajukan pemerintah untuk memberikan iklim kondusif dalam berinvestasi. Pencabutan kewenangan pemerintah provinsi dan kabupaten/kota dalam penataan ruang melemahkan sisi pengawasan pengendalian pemanfaatan ruang yang selama ini merupakan kewenangan pemerintah provinsi dan kabupaten/kota. Pengaturan ini ke depannya, tentunya akan menambah parah kerusakan lingkungan di setiap wilayah. Akibatnya bisa dipastikan kejadian banjir akan semakin meningkat sebagai dampak lanjutan dari meningkatnya kerusakan lingkungan di kawasan lindung.

Pengaturan penetapan minimal $30 \%$ merupakan kawasan lindung dalam suatu wilayah sebagaimana diatur dalam UU Penataan Ruang masih diperlukan. Pemerintah seharusnya mendorong daerah yang belum memenuhi ketentuan minimal 30\% wilayahnya merupakan kawasan lindung, untuk memenuhi ketentuan tersebut. Upaya mengalihkan kawasan lindung yang telah berubah fungsi tersebut kembali ke peruntukan awalnya sesuai fungsi diperlukan. Selain penegakan hukum perlu dilakukan untuk menindak pelanggaran dalam pemanfaatan ruang.

\section{Daftar Pustaka}

Alimansyah, A. (2011). Penyimpangan Pemanfaatan Ruang (Studi Kasus Alih Fungsi Lahan Sawah Beririgasi Teknis di Kawasan Danau Dusun Besar Kota Bengkulu. Yogyakarta: Universitas Gadjah Mada.

BNPB. (2020a, March 17). Infografis Update Bencana Tgl. 13 Mrt 2020 Pk.10.00 WIB. Retrieved from 
https://bnpb.go.id/infografis/infografis-updatebencana-tgl-13-mrt-2020-pkl-10-00-wib-, on April 14, 2020.

BNPB. (2020b). Data Informasi Bencana Indonesia. Retrieved from https://bnpb.cloud/dibi/ laporan5a, on April 14, 2020.

BNPB. (2020c). Bencana Alam di Indonesia Tahun $2010 \mathrm{~s} / \mathrm{d}$ 2020. Retrieved from https://bnpb. cloud/dibi/grafik1a, on April 14, 2020.

BNPB. (2020d). Data Informasi Bencana Indonesia. Retrieved from http://bnpb.cloud/dibi/, on April 14, 2020.

BNPB. (2020e). Data Informasi Bencana Indonesia. Retrieved from http://bnpb.cloud/dibi/, on April 28, 2020.

BNPB. (2019, May 2). Infografis Bencana Banjir dan Longsor Bengkulu. Retrieved from https://bnpb. go.id/infografis/infografis-bencana-banjir-danlongsor-bengkulu, on April 14, 2020.

Bieri, S. (undated). Disaster Risk Management and the Systems Approach. DRM World Institute for Disaster Risk Management. Retrieved from http://www.drmonline.net/drmlibrary/pdfs/ systemsapproach.pdf, on December 9, 2019.

Bungin, B. (2006). Metodologi Penelitian Kualitatif, Aktualisasi Metodologis ke Arah Ragam Varian Kontemporer. Jakarta: Raja Grafindo Persada.

Center for Excellence in Disaster Management \& Humanitarian Assistance. (2018). Indonesia Disaster Management Reference Handbook. Hawaii: Center for Excellence in Disaster Management \& Humanitarian Assistance.

Dinas Lingkungan Hidup dan Kehutanan Provinsi Bengkulu. (2017). Renstra Dinas Lingkungan Hidup dan Kehutanan Provinsi Bengkulu Tahun 2016-2021. Bengkulu: DLHK Provinsi Bengkulu.

Edriani, A. F. (2014). Analisis Tingkat Erosi dan Kekritisan Lahan Menggunakan Sistem Informasi Geografis di Sub DAS Bengkulu Hilir DAS Air Bengkulu. Skripsi. Fakultas Teknik Universitas Bengkulu.

Eriyanto. (2009). Analisis Framing. Yogyakarta: Lkis Yogyakarta.

Faisal, A. (2020, January 20). Bengkulu Darurat Sampah, Dewan Kota Usulkan Sampah Dikelola Pihak Ketiga. Republik Merdeka. Retrieved from https://www.rmolbengkulu. com/read/2020/01/20/21823/Bengkulu-Darurat-
Sampah,-Dewan-Kota-Usulkan-SampahDikelola-Pihak-Ketiga-, on May 29, 2020.

Firmansyah. (2019, May 1). Gubernur Bengkulu Ungkap 4 Penyebab Banjir dan Longsor. Kompas.com. Retrieved from https://regional. kompas.com/read/2019/05/01/12133071/ gubernur-bengkulu-ungkap-4-penyebab-banjirdan-longsor, on June 21, 2019.

Firmansyah \& Halim, D. (2019, May 2). 7 Fakta Bencana Alam di Bengkulu, 4 Penyebab Banjir hingga Perusahaan Tambang Bantah Jadi Biang Keladi Bencana. Kompas.com. Retrieved from https://regional.kompas.com/ $\mathrm{read} / 2019 / 05 / 02 / 14554261 / 7$-fakta-bencanaalam-di-bengkulu-4-penyebab-banjir-hinggaperusahaan-tambang?page=all, on May 28, 2020.

Frastien, D., Iskandar, \& Satmaidi, E. (2018). Pemanfaatan Ruang Berdasarkan Rencana Tata Ruang Dalam Upaya Perlindungan Kawasan Taman Wisata Alam Pantai. Supremasi Hukum: Jurnal Penelitian Hukum. 27(1), 1-22.

Halim, F. (2014). Pengaruh Hubungan Tata Guna Lahan dengan Debit Banjir pada Daerah Alirah Sungai Malalayang. Jurnal Ilmiah Media Engineering, 4(1), 45-54.

Harahap, N. (2014). Penelitian Kepustakaan. Jurnal Iqra', 08(01), 68-73.

Hindarto, K. S., Hidayat, M. F., \& Depari, E. K. (2013). Aplikasi Sistem Informasi Geografis (SIG) untuk Pemodelan Spasial Disain Tata Guna Lahan DAS Lemau Berdasarkan Tingkat Kekritisan Daerah Resapan. Laporan Penelitian Hibah Bersaing Universitas Bengkulu.

Hutapea, E. (2019, January 26). Bencana Banjir di Sulsel Disebut Akibat Penyalahgunaan Tata Ruang. Kompas.com. Retrieved from://properti. kompas.com/read/2019/01/26/161937921/ bencana-banjir-di-sulsel-disebut-akibatpenyalahgunaan-tata-ruang, on June 21, 2019.

Kementerian ATR/BPN. (2019, August 28). Terdapat 6.621 Lokasi di Indonesia Terindikasi Melanggar Tata Ruang. Retrieved from https://www. atrbpn.go.id/Berita/Siaran-Pers/terdapat-6621lokasi-di-indonesia-terindikasi-melanggar-tataruang-93911, on April 28, 2020.

Kirana, P. H., Hizbaron, D. R., \& Hadi, P. (2017). Pengaruh Curah Hujan dan Perubahan Penutup Lahan Terhadap Banjir di Kabupaten Bandung Tahun 1995-2015. Jurnal Bumi Indonesia, 6(4), tanpa halaman. Retrieved from http://lib.geo.ugm. ac.id/ojs/index.php/jbi/article/view/926/898. 
KLHK. (2018). Data dan Informasi Pemetaan Tematik Kehutanan Indonesia: Penutupan Lahan Indonesia, Deforestasi Indonesia, Moratorium Hutan Alam Primer dan Lahan Gambut. Booklet Informasi Pemetaan Tematik Kehutanan Indonesia.

KLHK. (2019a). Rekalkulasi Penutupan Lahan Indonesia Tahun 2018. Jakarta: KLHK.

KLHK. (2019b). Statistik Lingkungan Hidup dan Kehutanan Tahun 2018. Jakarta: Pusat Data dan Informasi KLHK.

Media Center Pemprov Bengkulu. (2019, Agustus 29). Pemprov Bengkulu Gelar FGD Audit Tata Ruang di Kawasan Pesisir. Retrieved from https://bengkuluprov.go.id/pemprov-bengkulugelar-fgd-audit-tata-ruang-di-kawasan-pesisir/, on May 28, 2020.

Miardini, A., Gunawan, T., \& Murti, S. H. (2016). Kajian Degradasi Lahan Sebagai Dasar Pengendalian Banjir di DAS Juwana. Majalah Geografi Indonesia, 30(2), 134-141. doi: 10.22146/mgi.15633.

Mirzaqon, A., \& Purwoko, B. (2018). Studi Kepustakaan Mengenai Landasan Teori dan Praktik Konseling Expressive Writing. Jurnal BK-Unesa, 8(1), 1-8.

Nurhamidah, Junaidi, A., \& Kurniawan, M. (2018). Tinjauan Perubahan Tata Guna Lahan Terhadap Limpasan Permukaan Kasus: DAS Batang Arau Padang. Jurnal Rekayasa Sipil (JRS-UNAND), 14(2), 131-138. doi: 10.25077/jrs.14.2.7380.2018 .

Nurjanah, R. S., Dede, K., \& Adikoesoemo, S. (2012). Manajemen Bencana. Bandung: Alfabeta.

Nurrizqi, E. H., \& Suyono. (2012). Pengaruh Perubahan Penggunaan Lahan terhadap Perubahan Debit Puncak Banjir di Sub DAS Brantas Hulu. Jurnal Bumi Indonesia, 1(3), 363371, http://lib.geo.ugm.ac.id/ojs/index.php/jbi/ article/view/104/101.

Naskah Akademis RUU Cipta Kerja (2020).

Ramon, A. \& Afriyanto. (2015). Karakteristik Penanganan Sampah Rumah Tangga di Kota Bengkulu. Jurnal Kesehatan Masyarakat Andalas, 10(1), 24-31.

Rijanta, R., Hizbaron, D. R., \& Baiquni, M. (2014). Modal Sosial Dalam Manajemen Bencana. Yogyakarta: Gadjah Mada University Press.
Ronald. (2019, April 30). Faktor-Faktor Terjadinya Banjir Bengkulu yang Tewaskan 29 Orang. Liputan6.com. Retrived from https://www. liputan6.com/news/read/3954170/faktor-faktorterjadinya-banjir-bengkulu-yang-tewaskan-29orang, on May 29, 2020,

Rosyidie, A. (2013). Banjir: Fakta dan Dampaknya, serta Pengaruh dari Perubahan Guna lahan. Jurnal Perencanaan Wilayah dan Kota, 24(3), 241-249.

Rustiadi, E., Sunsun, S., \& Panuju, D. R. (2017). Perencanaan Pengembangan Wilayah. Edisi Kedua. Jakarta: Yayasan Pustaka Obor Indonesia.

Sandi, R. Z., Iskandar, \& Komar, M. Y. (2017). Penataan Ruang Terbuka Hijau di Kota Bengkulu Berdasarkan Peraturan Daerah Kota Bengkulu Nomor 14 Tahun 2012 tentang Rencana Tata Ruang Wilayah Kota Bengkulu Tahun 20122032. Skripsi. Fakultas Hukum Universitas Bengkulu. Retrieved from http://repository.unib. ac.id/id/eprint/14188.

Satmaidi, E., Muthia, A. A., \& Wulandari. (2018). Konsep Hukum Pengelolaan Tambang Batubara Berkelanjutan Berdasarkan Pendekatan Daerah Aliran Sungai (DAS) di Provinsi Bengkulu. Bina Hukum Lingkungan, 2(2), 198-214. doi: 10.24970/jbhl.v2n2.16.

Sitorus, S. R. P., Mustamei, E., \& Mulya, S. P. (2019). Keselarasan Penggunaan Lahan dengan Pola Ruang dan Arahan Pengembangan Ruang Terbuka Hijau di Kabupaten Bengkulu Selatan. Jurnal Ilmu Tanah dan Lingkungan, 21(1), 2129. doi: 10.29244/jitl.21.1.21-29.

Sulaeman, D., Pradana, A., \& Hamzah, H. (2019, July 31). 3 Faktor Utama Penyebab Banjir di Indonesia dan Bagaimana Mencegahnya. Retrieved from https://wri-indonesia.org/id/blog/3-faktorutama-penyebab-banjir-di-indonesia-danbagaimana-mencegahnya, on May 28, 2020.

Triutomo, S., Widjaya, B. W., \& Amri, M. R. (Eds.). (2007). Pengenalan Karakteristik Bencana dan Upaya Mitigasinya di Indonesia. Edisi II. Jakarta: Direktorat Mitigasi, Lakhar BAKORNAS PB.

Undang-Undang tentang Penataan Ruang (2007).

Umar, I. \& Dewata, I. (2018). Arahan Kebijakan Mitigasi pada Zona Rawan Banjir Kabupaten Limapuluh Kota, Provinsi Sumatera Barat. Jurnal Pengelolaan Sumberdaya Alam dan Lingkungan, 8(2), 251-257. doi: 10.29244/jps1.8.2.251-257. 
Wardhana, P. N., Yuni, S. A., \& Kurnia, D. (2018). Pengaruh Perubahan Tutupan Lahan Terhadap Debit Banjir di DAS Winongo Daerah Istimewa Yogyakarta. Jurnal Ilmiah Teknik Sipil, 22(2), 157-164. doi: 10.24843/JITS.2018.v22.102.p10.

Ward, R. C. (1978). Floods: A Geographical Perspektif. London: The Macmillan Press.

Warsilan. (2019). Dampak Perubahan Guna Lahan Terhadap Kemampuan Resapan Air (Kasus: Kota Samarinda). Jurnal Pembangunan Wilayah, 1(1), 69-82. doi: 10.14710/pwk.v15i1.20713.

Wiryono, Senoaji, G., \& Fajrin, H. (2015). Studi Daya Tampung dan Daya Dukung Lingkungan Daerah Aliran Sungai (DAS) Air Bengkulu. Project Report Fakultas Pertanian Universitas Bengkulu.

Yulaelawati, E., \& Syihab, U. (2008). Mencerdasi Bencana. Jakarta: PT. Grasindo.

Yusup, I. (2019, June 29). Ini Penjelasan DLHK Terkait Perubahan Fungsi Kawasan Hutan Provinsi Bengkulu. Bengkulunews.co.id. Retrieved from https://www.bengkulunews.co.id/ini-penjelasandlhk-terkait-perubahan-fungsi-kawasan-hutanprovinsi-bengkulu/, on April 28, 2020.

Zed, M. (2008). Metode Penelitian Kepustakaan. Jakarta: Yayasan Obor Indonesia. 